\title{
STUDIES ON THE NATURE AND FORMATION OF THE OTOLITH
}

\author{
$\mathrm{By}$ \\ Y. SAKAGUCHI \\ From the Department of Oto.Rhino.Laryngology, Tottori University \\ School of Medicine (Director: Prof. H. Sasaki)
}

Otolith and Maculae were removed in the condition as fresh as possible by means of the particular method from frog, guinea-pig and hen. The nature and formation of otolith were studied and the results were as follows:

(1) It was shown by pressure method, $\mathrm{X}$-ray diffraction technique and electron microscope that the otolith was in a gel-like condition in vivo. But when otolithic membrane lecame to non-physiological condition by the chemical and physical stimuli, the extremely samll crystals got to gather and developed to form the otolith which has been observed as large crystals.

(2) $\mathrm{Ca}^{45}$ was used as a tracer to study the formation of otolith. The rise and fall of $\mathrm{Ca}^{45}$ as tracer were investigated. $\mathrm{Ca}^{45}$ moved rapidly to the otolith and mostly disappeared in 72 hours aftet the injection. It seemed that thete were calcium metabolism was present in the otolith.

(3) Carbonic anhydrase was demonstrated in the otolithic organs of hen and frog, especially in high concentration in the otolithic membrane and so called Smith's extramacular portion.

(4) As the results of the administration of various enzyme inhibitors, it was demonstrated that carbonic anhydrase was related to the formation of calcium carbonate in the shell.

(5) From these studies, it seems that carbonic anhydrase plays an important part in the formation of otolith.

\section{耳石の本態並びに形成に関する研究}

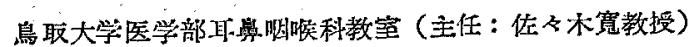

目次

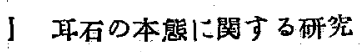

1. 緒言

2. 压迫実踰

緒 言 材料普びに方法
成縝 小 括

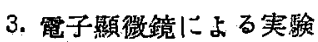

緒 言、材糊並びに方法

成綪 小括

4.X 線湎行による䒠験

綃吉材料並びに方法

成 綪 小 括

5. 稳括並びに拷按

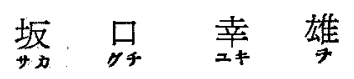

1 耳石の形成に関する研笁

1. 緒 言

2. $\mathrm{Ca}^{45}$ による $\mathrm{Ca}$ 代謝の研筲

緒言材料並びに方法

成緋 小括

3.組織化学による C.A. の証明

綾䓂材料並びに方法

成維 小括

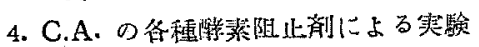

絠 言 材料並びに方法
战 絽 小 括

5. 総括羊びに溚挍

III䋨: 論 


\section{I 耳石の本態に関する研究}

\section{1. 緁言言}

工不の本態に閶する砳究としては, 船岡, 椑田 ${ }^{13)}$

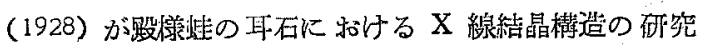
によつて，初めて蛙耳石を Aragonite であると決定し て以来, 20 数年間といらものは，生物の耳石は総べて Aragonite であると信じられてきたのである・ところ

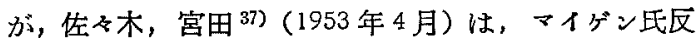
忘，電子顕微鏡，X線迴折，等に上り，人間，家兔， ッテ等の陠乳動物の耳石は Calcite である事を発見し， 発表したのである. 次いで Engström, Carlström4) （1953 年11月）も全く同嵄な率害を報告した。その後， 佐々木，宮田 ${ }^{3 *)}$ (1955) は更に矿究を進める中に，生

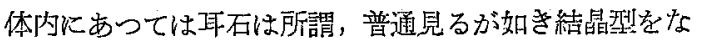
して居らず，耳石膜に包まれて一程のカルシウムのコロ イド状態として存在し，お互いに吸引し合い，又民撥し 合つて平衡を保ち存在するのであり，従って生体内にあ る時は耳石は白色泥状をなしてはいるが，摘出等によ り容易にその平衡状態が破られ引力であるVan der Waals 力が強く作用し，水分を脱して固まり，結晶型 を形成してくるのではなからうかと推論したのである。

ところで，現在に至るまで，かような生体内に和ける 耳石の態度を実墟的に追求した報告は見ないのである。 著者は先に佐々木, 宮田が提示した耳石の本態に関して これを徹底的に探索する意图をるつて，引続き次のよう な実験を行ったので，竝汇報告する次第である。

\section{2. 压迫実験}

\section{緒 言}

先に述べた如く耳石の染色性の研究に端を発し，佐る

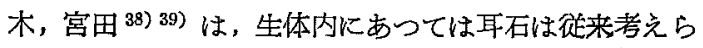
れていたよらな大なる結晶としては存在せず，一稙の岸 酸カルシゥムのコロイド状態として，存在するのである らとの推論を提示したが，これをさらに追求する目的で 次のような実験を行い成續を得たので報告する。

材料並びに方法

実験動物には㔀渌蛙を使用した。

両側前庭迷路を破壊し，白色泥状の耳石塊を針先にて 摘出する・そして試驗片としては，二枚の厚がラス（厚 さ $5 \mathrm{~mm}$, 綖 $8.5 \mathrm{~cm}$, 横 $2.5 \mathrm{~cm}$ )を用い（図 1 ), そのガ ラス板の間に先に述べた耳石を插入する.垁験装置とし ては, 理研計器怢式会社の光弾性笑験装置を用いて試鮯 片に荷重を加えたま〉，前後左右に移動できるもので，

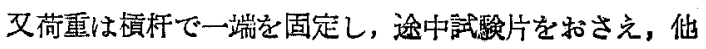

第 1 图

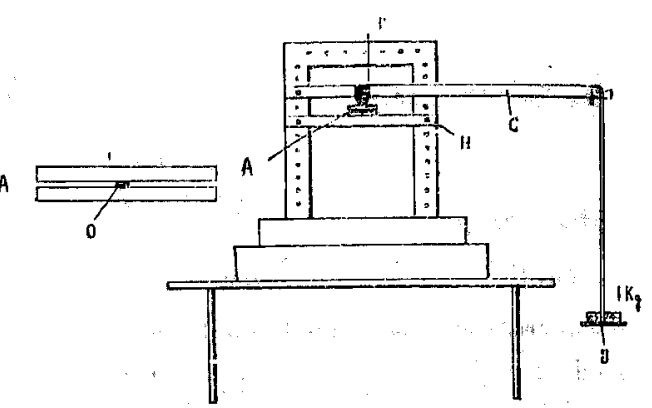

街重装埴模圈図

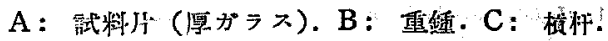

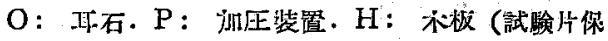
持板)

の䍡に鉄製重錘を適宜增減して荷重することができるむ ので，本医学部で作成されたすのである (図1参照). この場合はこれに $1 \mathrm{~kg}$ の重鍾を荷重し，一往復の砳祭 を行つたのである. 以上の装置の元で摘出直後のるの と，乾燥したるのとに大別し；乾燥したものではその時 間的経過に従つて観察した. その際直後のむので恃次の ような方法を用いた．即ら助手に二枚のがンス板の間に 直ちに資料が塖入できて，更に同時に荷重が加わる状態 に準備をさせ，一方ではガラス板の横で耳石の摘出を行 い瞬時にこれをガラス板上にのせ上記の操作を試みた。

$$
\text { 成 綪 }
$$

かようにして行つた摘出直後のものでは砂粒状，顆粒 状をなした大きさ約 $0.1 \mu$ の耳石が権察されるのみであ つたが (写真 No.1)，これに反して乾燥したものでは， 即ち摘出後 5 分を経過してや〉乾燥した耳石では同様な 操作を加えて検鏡したところ，一部础粒状ではあるが， 大部分は判然とした $1 \mu \sim 10 \mu$ 程度の結晶型を示した(写 真 No.2). 更に 10 分間 20 分間乾燥した後の資料にっ いて試みた結果は殆んど大なる結晶型を示し，一部には 耳石の崩萝したと思われる小片が散在性に観察されたの である・

\section{小 括}

以上の実臨上り摘出直啳のものでは砂料状，顆柆状下 なつた耳石が，更に乾燥した資料では一部砂粒状であつ ても，かなり判然とした結晶型を呈しているのを知り， 両者の間には劃然たる美異のあるのを認める事がでを た。

\section{3. 電子顕凯鏡による実験}

緒 言 
各部門において最近電子顕微鏡が普及し，現在まで末 知とされている諸問題が炊々と究明せられ，吾が耳奥咽 唉积学領域に和いても，濑〈新しい分野が開拓されつ〉 ある: そこで私は引続きこれを使用し耳石の生体内におる ける状熊をさらに究明しようと思い，ょり生体に近い状 態に拈いて，次のよらな実験を行つたのである。

材料並びに方法

実験動物には殿倳蛙を使用した。

先ず摘出直後の耳石を予め用意して打いた載物硝子上 のヘマトキシリン（アルカリ性の）の溶液に混入し空気 中で乾燥後, 水洗し, 更に充分乾燥させた後，その耳石 の一部を取り雷子顕微鏡 (JEM-4C 型日本電子光学矿 究所作製）により至細にわたり観察した。

\section{成 繬}

以上のよらな観察から光学顕微鏡で見た顆粒状の物質

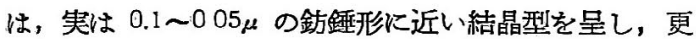
にこの一つの結晶型は写真に (写真 No.3，4) 示される 上うな非常に微細なる約 $0.005 \mu$ の大きさ略々一定せる 粒子よりなつている所見を得ることができたのである. な和，染色せずに摘出し乾燥した耳石にあつては，1〜 $20 \mu$ 程度の大なる耳石塊として観察された。

\section{小 括}

ヘマトキシリンにより染色された場合は，諯細な粒子 表面に色录顆粒が吸着され，耳石の凝結現象が妨げ られた結果，写真に見られる以上のような微細な顆 粒の集合として観察されたのであるが，染色しない 場合は，漸次乾燥し，水分を脱して，か上らな微細 顆粒が相結合し，先に述べたよらな大なる結晶型を 形成したものである。

\section{X 線廻折による実験}

\section{緒、言}

生鮮な乾燥しない耳石について，X 線廻折実験 は未だからて行われていないのである・しかるに今 回，著者は生体内にあって，耳石は果していかなる 壮態で存在しているものがどうかを知るために，上 述の圧追実嗝，電子顕微鏡観察により生体内耳王は コロイド壮態にて存在する事を殆んど実部し得たの であるが，更にこれを決定付けんとして，X 線廻 折実験を行つたのである.

\section{材料並びに方法}

実験動物としては，殿様蛙，250〜300gr の正常 海猲を使用した。

さて蛙 33) の膜性迷路（大半は耳石てて占められ ているが）は婹に包まれて存在している。この篂
は横立の顿骨附属物により合一せる二個の骨部に团続せ られ，外側性後頭骨は耳唯の後部，前耳，胃はその前部を

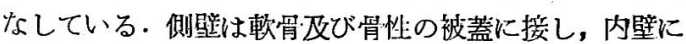
物いては数多くの開口が認められ，こっょり聴神経リ ンパ管が出でいるそとこで先ず断頭後，外側頭骨を切除 し，耳嫼の一部を露出して，後内壁に和いて針筸で入念 にリンパ管及び聴神経を切断し，この断端を尖鋭なピン セットにて固く把持し，緩除に跭が破れない状態の完全 なる耳戙を取り出した。

かようにして取り出した耳郦を破噮しないように慎需 に，予め作製した值経約 $5 \mathrm{~mm}$ ，長さ約 $1 \mathrm{~cm}$ のセロテ 一プの略々中央に入れ，次に述べるらうな方法で実験に 供したのである。こつで著者はX 線廹折法として， Debye Scherrer 不び Hull の法に基づいて実艮を行 つた・即ち，銅を刘陰極とする Coolidg 管球より一定 波長の $\mathrm{X}$ 線 ( $\mathrm{CuK} \alpha$ 線) を出し，これを管球より 10 乃至 $15 \mathrm{~cm}$ 後方の上記の試料にあて，その反射 X 線を 訟料周因に存する 直径 $10 \mathrm{~cm}$ の円筒侨! カメシにて撮影 する方法である (X 線画折装置は図 2 参照)。な括この 際フィルターとしてはニッヶルを用いた・フィルムはニ ダックのX線フイルム（富士 X 線フイルムの約3〜 5 倍の感光度を有する）を使用し，管電圧 $33 \mathrm{KV}$, 電流 $33 \mathrm{MA}$, 焦点距離 $10 \mathrm{~cm}$, 露出時間 10 分, 海猽では電圧

第 2 図

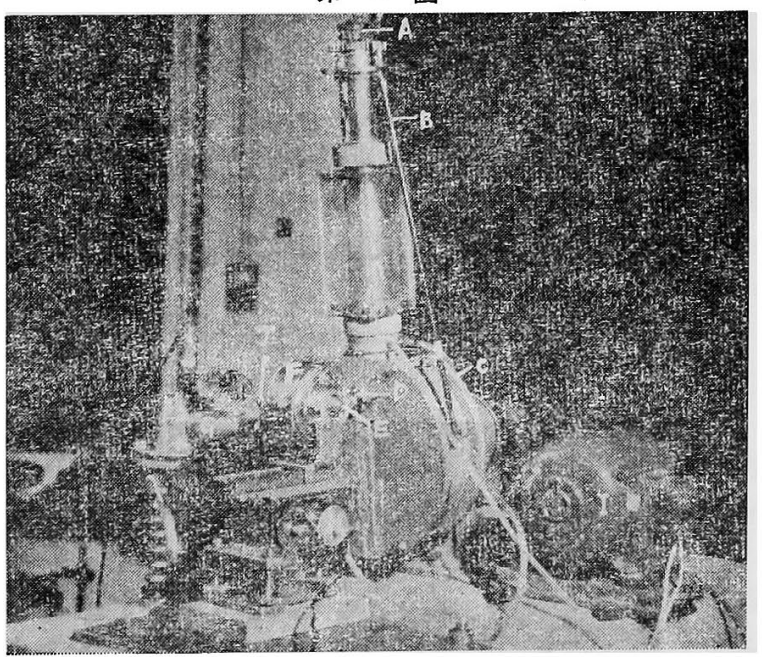

$\mathrm{X}$ 線回航落㙁

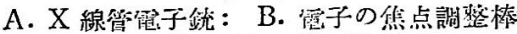

C. 趣枟陽極 X 䋊篦：D. X 線出口

E. 試料軕：F.フイルム七ット：G. 票空引口

H. デバイ裝置のマウント：I. 劭極超枟モータ

ー：J. ビームトラップ 
$35 \mathrm{KV}$, 電流 $35 \mathrm{MA}$, 焦点距離 $10 \mathrm{~cm}$, 露比洔間 23 分に して撮影した結果，解明なる廷折写直を撮ることがでさ た・この場合試料の延転は行わなかつた（表 1 ).

\begin{tabular}{|c|c|c|c|c|c|c|}
\hline 動物 & 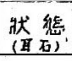 & 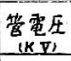 & \begin{tabular}{|c|} 
電流 \\
\end{tabular} & 焦卓距焠 & \begin{tabular}{|c|c|} 
露出時阔 \\
分
\end{tabular} & 試料回转 \\
\hline 蛙 & 生 鲜 & 33 & 35 & 10 & 10 & $(-)$ \\
\hline 蛙 & 乾燥 & 33 & 33 & 10 & 10 & $(-)$ \\
\hline 海䐎 & 生鮮 & 35 & 35 & 10 & 23 & $(-)$ \\
\hline 海梖 & 敦㴪 & 35 & 35 & 10 & 23 & $(-)$ \\
\hline
\end{tabular}

かくて X 線により結晶の迴折像が干洗環 (D-S 環) として撮影され，この区形あるいは線の強さ等は，各結 昆に上り固有で，これ等より結暃系の推定，結晶粒子の 大きさを判定するわけである。

\section{成 續}

先づ自然に存する結;暃型の確定された霞石の結晶，及 び先に実験に供した耳麗を破り取り出して乾燥した耳石 について，X 線廹折を行つた結果，勿論，霞石の D-S 環に一致しているのを認めたのであるが，これ等は DS 環上にぶつぶつ状の砂粒状の斑点として現われ（写真 Nc.5), 生鮮の壮態にある耳石では，矢張り霞石と同じ D-S 環ではあるが，一椾に色附いた鄁漫性の環として 認めたのである（写真 No.6, 図 3). 後者のぶつぶつ状 の斑点は，結晶粒子が波長に比して粗大なるため生すする もので，結晶が $1 \mu$ 以上の大きさを持つ事を意跦し，又 斑点なき環は粒子が $0.1 \mu$ 以下の做細なものである事を 表わしているのである。

海獏の埸合も㤬耳石の場合と同樣に 乾燥したもので は，D-S 環上にぶつぶつの斑点として現われ（写真

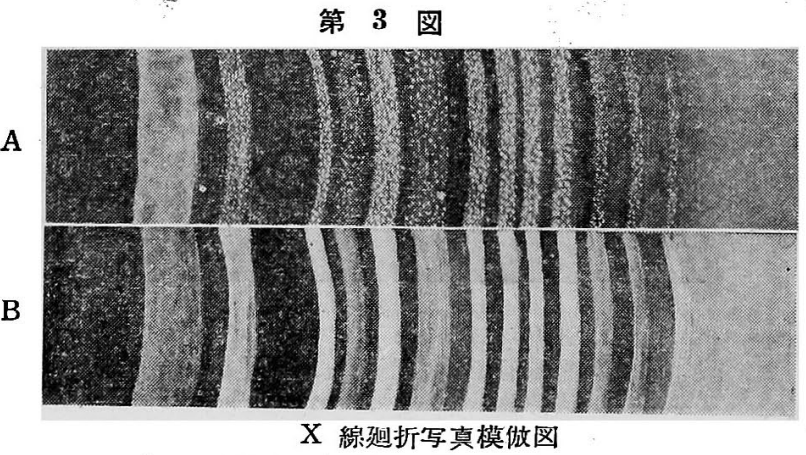

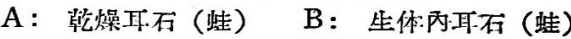

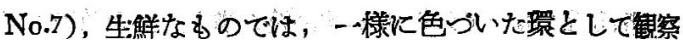
された (写真 No.8).

小 括

以上の両者の相違からして，著者は耳不は生体内にあ つては，今まで考觉られていたよらな結晶の集りではな く, $01 \mu$ 以下の一種の炭酸カルシウムの微粒子即ち， コロイド状態として存在している事が確実信えると思 万.

即ら炭酸カルシウム極微粒子が分散某となり，蛋白質 が分散質として平衡を保つ一種の=ロイドが形成されて いると云える。

\section{5. 総括亚びに考按}

圧迫実験

先つ上記実験の前段階として著者は摘出直後の耳石を 二枚の厚ガラス板の間に拂み，指先きにて压を加えて観 察する方法を試みていたのであるが，か様な方法では， その正確なる圧を規定することが不可能である・従って 更には一定の圧力を得られる Air Compressure を使 用して，直接資秢に压を与.える方法をとつたが，資粉が 四散するため，不成功に終った．そこで一定の荷重を加 える装置があれば，理想的な方法であらうと，璉検討 した上, 全く独創的な方法として, 先の光弾性実験用具 の一部である荷重装置の利用を思いたつたのである：さ て生:体内にある耳石は一度, 空気中に懪露されると, 速 やかに乾燥され易い性状をるつている. 従つて据吠直後 のものについては，非常に迅速なる奶置が必要である. ために全く瞬時に操作でき得る体勢に準備した・所謂耳 不は，生体内にあつては，白色泥状をなしている，この 事.実は生体内では耳石とのものが柔き饬質として存在し ているのか，あるいは，硬固な結晶であるのか，それを 含む周聿のゲラチンよう物質のために柔かいるのとして 感ずるのか，今仮に耳石が硬固なる結晶であ ると仮定すると，軽微な开追では容易に崩壊 しない筈である・ところが以上の実験によ り，著著は生:休内にあっては，耳石は硬固な 綡:晶ではない事を立証したことななる・

電子顕微鏡による実験

一般に一個の耳石は，それ自身，それ气れ 単結晶のように考えられていたが，染色しな い状態の耳石を電子顕微鏡で勧繁すると，矢 張り大なる 単箱:唱様の像として現われてく る. しかるに Engström と Carlström ${ }^{4)}$ (1955) は人閒の耳石を 圧し潰し，これを曹 
手顕微镜で険索した結果，実は単一結; 晶を示さない微細 結晶の集合のように思克ると報告している・一方佐々 木，㗬田は同年，摘出して殆んど乾燥しない悽の耳石を ヘマトキシリン中に混入し，これを電子顕微鏡で観察し た結果は，微細結晶型が次第に融合し大なる結晶型を呈 する像をとらえることに成功した・しかるに前者は飽く まで乾燥しない，儘の状態で，後者は全く乾燥した状態 の耳石について試みられたものであって，両者間にはそ の出発点に明らかな相遥があり，又との結果は，先の圧 迫実験がこの事実を明らが意味づけていると思う。

更に今回行つた実験から（摘出直後の耳石を間䈍を入 れずへマトキシリンに混入した結果)，佐々木，宮田 ${ }^{39}$ の云ら一つの微細結晶型は，実は更に微細なる粒子より 構成されていると云ら所見を得たが，このことは生体内 にあつては，耳石は一䡛の㟶酸カルシらムの微粒子即 ち. ニロイドの状態として存在するすのであろらとの推 論をより確実にする事ができた。

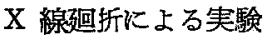

$\mathrm{X}$ 線廹折法汇は種ぬあるが，極めて微細な結晶の決 定には，粉沫法が賞用されているが、これは更に試料の 作り方，及び撮影方法により二璉類に分類できる・著者 は Debye-schrrer 及び Hull の法に基づいて実馱を行 つた. その結果，耳石膜を破り取り出した耳石を乾爆さ せて後撮影したものでは, Aragonite 及び Calciteを 示してはいるが，各環輪は明らかに著明なら゙つぶつの斑 点を認め，決して濔慢性ではないのである・これに反し て、耳石膜を全く破らない儘の即ち生体内耳石をX 線 甶折した結果は，矢張り Aragonite及び Calcite 特有 の干啮環ではあるが，明らが源慢性同一色調として現 われた・以上のよらな実験結果から，從来考えられてい たよらな大なる耳石結晶の集合体は耳石膜が破れると か，他の化学的影響をうけて，その微結晶質が相集つて 結晶の成長をなしたものであり，生体内では炭酸カルシ ウムのコロイド状態として存在していると云う推論に重 要なる根拠を与えたものと確信する。

\section{II 耳石の形成に関する研究}

\section{1. 緒言}

耳石の発生に関しては，Wittmaack ${ }^{30)}$ (1919), Studnicka 23) (1921)，Donadai 9) (1925) が，德斑の上皮 細胞は一種の分汹機能を有することを報告し, 又 Cup-

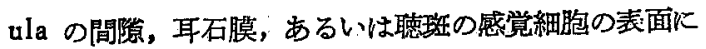
見出されると言ら滴状の球形形成物を Donadai 9)は一

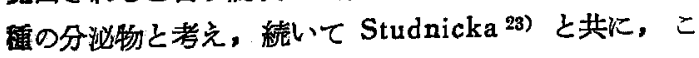

れをOtoconien と名附けた.その後、この事は西尾 ${ }^{18)}$ （1926）の追試に上り標本作製時の誤锩であると反対さ れた。

更にその後 Wittmaack 30)（1930）は実驗進展さ せ，膠様質上の Otolithenは Endolymphより沈淈と して生じたるのであると主張した。

一方 Herzog 15) (1925) は, 耳石は上皮細胞の 原形 質より生成されるむの机ず先つ上皮細胞より「ュロ 1 ア゙」分泌せられ，これに值接㟶酸カルシウムが沈着し て, 生成されてるのであると述べ, 文西尾 ${ }^{18)}$ (1926) は 実騟的に「マクラ」に近き部の内リンパはその部の上皮 の作用により宸酸カルシウムの含量が濑次堌大し豊富と なり，逆湠酸カルシウムを沈降省るに至る事実を認る ている.

それ以来といらるのは，耳石形成乃至は発生に関する 砄究は，殆んど停滞した感があつたが，最近になり， Vilstrup 25)（1951）鮫を用い内淋巴管の上皮の中に， あるい管腔内に，又耳石膜の中にVacuolesを見出 し、これを種々な方法炕より検索し，この Vacuoles は, 炭酸っルシウムを含んでいるように思われ，内淋巴 上皮より分泌されたV Vacuoles は内淋巴管に移動し，聴 斑上の耳石膜の中に入つてくると述べている. 更に，こ の Vacuoles は Donadai, Studnicka 等の言ら分泌物 と一致している. 即ら，彼は内淋巴管上皮に分汹機能を 有する事を認めているのである。

次いで Savin7) は (1955) Chickenembryo を使用 し, 䀧畉 5 日目の Gallus domesticus embryo K拉 いて, endolymphatic sac 中にカルシウム物質の存在 を認め，上皮細胞あるいは，内リンパ管中に結晶を形成 する力をるつているるのである事は注目すべきである と結論し，更に彼は ${ }^{8)}$ 翌年，孵卵9日目の Chicken embryo の内淋巴䃄内に既に耳石は存在していたが， 特殊の神経終末，あるいは線毛細胞を欠除していること を証明した。

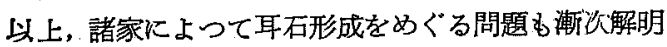
されてきてはいるが，な括不明の点も多く、現在もなお 推論の域を脱していないといってむ過言ではない。

さて，先に著者は耳石のコロイド説を再砗認し，耳石 形成の問題解決にもある光明を得ることができた・そこ で更に進えで，その問題究明に次のよらな実駰を行い， 所期の成樍を得たので報告する。

\section{2. $\mathrm{Ca}^{45}$ Kよる $\mathrm{Ca}$ 代謝の研究}

緒言 
生物は着分と呼ばれる一定の物質を体内に摂取して， 身体の内部で色々に変化させ個体の構成，生命の保持に 役立たせているが，その上うに変化した物質の内，一定 部分を体外に放出する・これ性命現象の一つの新陳代 謝と呼ばれる現象である。

しかるにか」る代謝，殊に Ca の代謝に関しては各方 面で研究がなされていたが，最近この面の研究に新しい 道程として、Camphell と Greenberg ${ }^{22)}$ が初めてア イットーブを物質代謝研究に応用し，それ以来各分野に おいて盛んに使用されるに至つたのである．著者も今回 初めて耳石形成を追究の目的で， $\mathrm{Ca}^{45}$ tracer とし て用い，炏のような実験を行い，いさつか知見を得るこ とができた・

材料並びに方法

放射性同位元素 $\mathrm{Ca}^{45}$ を用いた。 $\mathrm{Ca}^{45}$ は次のよ5な わのである.

Description $\mathrm{Ca}-45(\mathrm{P}-1)$

Specific activity : $75 \mathrm{mc} / \mathrm{gr}$

Analysis

Chemical Form: $\mathrm{Cacl}_{2}$

Concentration : $0.69+10 \% \mathrm{mc} / \mathrm{ml}$

Heavy metals : 1OP.P.M.

Normality: 1.32 Acid

$\mathrm{Ca}: 92.0 \mathrm{mgr} / \mathrm{ml}$

実験動物としては 250〜600gr の正常なる海猽, 区欠゙ 殿様蛙を使用した。

（1）海猽には $250 \mu \mathrm{c}$ ，殿様蛙には $20 \mu \mathrm{c}$ のを背部皮下 に注射し，種々の時間即ち海猉では 10 分間隔，蛙では 5 分間隔で断頭し実験に供した。

(2) 放射性同位元菜の耳石内推移及び耳石器官に括け る分布状態を知る手段とし、て次の方法を用いた。

ラジオオートグラフ (Radioautography)

ガイガーミニーラー計数管による測定 (G-M Coun. ter と略す)

ラジオオートグラフとは，標本中の放射性同位元素の 分布を写真孚闵膜に直接記録する方法である。

海狽に怙いては，断頭後，側副骨を取出し，入念儿銥 更ぴ針を以つて䄇円整が完全に明視しうる状態まで破壊 しこれを慎重に剔出し，承醰酸を含まないウイットマ 一っ氏溶液 (以下 $\mathrm{W}$-錯液と記す) 中に2〜3 日間固定 して後, 充分に水洗（約 24時間）後，ナルニールにて 脱水し、アルニール・ェーテル溶液に浸し，チェロイデ ン膜で載物硝子に貼布した。
その際，一側は． $\mathrm{Ca}^{45}$ 注射側，他側は非这射側とした (写真 No.11). 汃ようにした載物硝于上に瞕堂て FujiX-ray-film を一枚の中間紙を介在させて接着させ，黒 色紙にて覆い, 光を完全に遮断して、ゴム輪をかけ，各 標本は湿気を防止するために乾燥洞（塭化カルシウム） を入れた Decicater 中に安置し。これを低温保持のた め $1^{\circ} \sim 4^{\circ} \mathrm{C}$ の電気泠蔵庫内に入れ 10 日間露出して後,

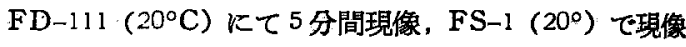
停正 1 分間, $\mathrm{FF}-\mathrm{H}_{4}\left(20^{\circ} \mathrm{C}\right)$ で 6 7 分間定着した.

蛙に和いては、3 群に分ち実験を行った。

（a）断頭後，耳缼を慎重に針先にて剔出し，整内より 耳石を殆しど除去した後，更に琵内をば注射器を用い蒸 溜水にて，何回も洗凩し，顕微鏡的に耳石なきを確かめ

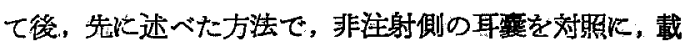
物碏子に耳慗の外面が硝子面に当る上うにして貼布し (写真 No.13), これに Fuji ET-2E Contact 型乾板 と一枚の中間紙を界し接着し，黒色紙て覆い，Deciater に入れ， $1^{\circ} \sim 4^{\circ} \mathrm{C}$ の温度に保ち，41 日間露出した. 露 出後は FD-111 $\left(20^{\circ} \mathrm{C}\right)$ で3分現像，FS-1 で現像停 止後, $\mathrm{FF}-\mathrm{H}_{4}\left(20^{\circ} \mathrm{C}\right)$ で 15 分間定着, 後 $20^{\circ} \mathrm{C} 30$ 分 間水洗した。

（b）注射後，種々の時間で断頭し，直ちに載物硝子上 に耳石を塗洙し，非注射側の耳石を対眧に乾燥するのを 待ち，例の如く中間紙を介在させ，Fuji-X-ray-film に接着し 3 日間露出後現像した（写真 No.9）.

(c) 断頭後, 雨側の耳霆を丁寧に剔出し, 化学天㭩に て秤量し, 更にこれと同重量の各内藏 (胿臟, 脾蔵, 俏 藏、骨，筋肉片）を取り，自己吸収，その他の影響を考

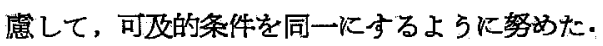

前記試料の一定量を，夫ょ60\%過塩索酸业びに，過 酸化水素を用い，湿性灰化せしめ，アンモニアにて， pH6.8 に補正し，飽和苳酸アンモニアを加えて沈搌せ しめ，生ず苳酸かルシウムの沈筑を更に，アンモニア にて洗淮啳。アルコール浮遊液として試料皿に入れ，赤 外線にて乾燥したものを，神戸工業の，G-M Counter （GM132）を用いて測定した。

測定条件 G-M 管よりの距離 $15 \mathrm{~mm}$

電圧 1125 Volts

海猉 $(800 \mu \mathrm{c} \sim 250 \mu \mathrm{c})$, 蛙 $(20 \mu \mathrm{c})$ 注射後, 種々なる

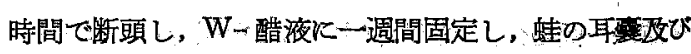

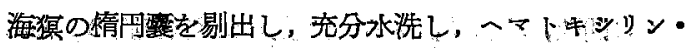

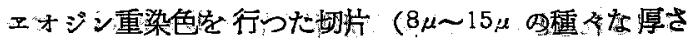

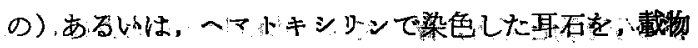


硝子に固定し，七ロイギン膜で覆い，更に，ゼラチン下 染 (0.5\% ぜラチン水溶液 $100 \mathrm{cc}, 1 \%$ クロ 明攀水溶 椎 $10 \mathrm{c}$ 使用直前に混合する)を施した，次しで乾板を

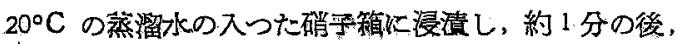

乳都膜が充分膨閏してから，在手で乾板を持ら，右手の 人差指の腹で乾板の四方の縁から乳成膜を静かに内側に こすると，直らに乳凧膜が硝子より剝ぐれる・この一辺 を右手でつ亲んで静かに反対側に引くと容易に乳凧膜の 劝溗離する。碃子板を除いて，代りに，上述した標本 を水中に入れ，その表面に附着している空気泡を完全に 除き，次炕左手て載物硄子標本面を上にして持ら，水办 で乳㓮唱を平らに広げて，静かに泡が入らず，異物が中 間に入らず，酦がよらないように注意しつょ，載物硝子

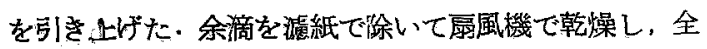
体を黑每紙にて覆い，前に述べたと同様な方法で露出

第 2 表 耳.石及各種䁍器队何の Ca45 の移行 (c.p.m.)

\begin{tabular}{|c|c|c|c|c|c|c|c|c|c|}
\hline & 筲程織 & 肝 & 葳 & 臊 & 臟 & 督 & 丽 & 耳: & 石 \\
\hline 30 分 & 130 & & 100 & & 70 & & 54 & & 15 \\
\hline 1 特間 & 140 & & 92 & & 60 & & 52 & & 17 \\
\hline $2 "$ & 140 & & 94 & & 50 & & 43 & & 20 \\
\hline $4 "$ & 130 & & 84 & & 58 & & 48 & & 14 \\
\hline $6 \geqslant$ & 114 & & 87 & & 54 & & 49 & & 22 \\
\hline $12 "$ & 120 & & 84 & & 59 & & 48 & & 24 \\
\hline $18=$ & 112 & & 80 & & 58 & & 40 & & 28 \\
\hline 24 & 78 & & 40 & & 35 & & 40 & & 28 \\
\hline 30 & 87 & & 37 & & 33 & & 38 & & $\approx 0$ \\
\hline
\end{tabular}

第 4 图 $\mathrm{Ca}^{45}$ の耳石內及各種䠰器丙滑長

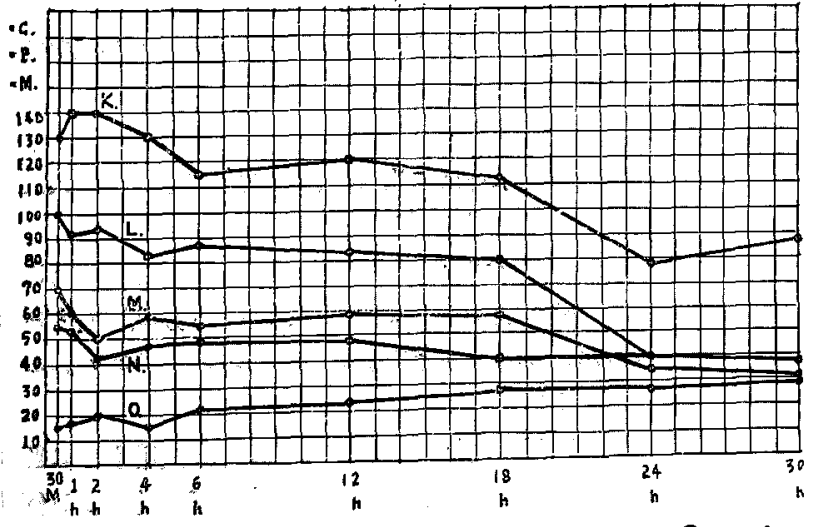

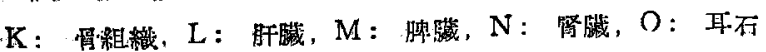

後、現像、定着及び水洗を行い検鏡した：この際特に露 出期間が長期沉亘るため，特に低温低湿に保ら，有害が スより守るために，Decicater 中の塩化カルシッムを 数回交换した・

\section{成 續}

以上の実験より，海埧の場命は注射後 1 時間にして。 渐く写真 (No.12) 亿示卞如き陰影飞認め，更に，蛙で は写真 (No.10) で見られるよらに15分後には，既に Ca ${ }^{45}$ が耳石内に移行している事実が判明したのである. 又興味あることは，蛙耳石膜に $\mathrm{Ca}^{45}$ の分布を認めたこ とである（写真 No.14）.

なお蛙では注射後 30 時間の観察から，他の藏器では 次第に減少するにも拘わらず，耳石内に执いては，除今 ではあるが，增加の傾向を見（表2，図4)，72時間で は殆んど消失するよらに思えた。

\section{小 括}

耳石がェロイド状態であるとすれば，耳石も矢張り， その他の骨組織と同様に Ca 代謝を営んでいる事が充 分想像されるのであるが，以上の実験からこれ等動物に 投与せられた $\mathrm{Ca}^{45}$ は，比較的速やかに耳石に集まる が，72時間程度で殆んぞ消失してしまら事実よりして 耳不は $\mathrm{Ca}$ 代謝を行つていると云つても䞠支えないと 思亏.

\section{3. 組織化学による C.A. の証明}

\section{緒言害}

骨格に沈着するCaは，主としてその橉酸塩として であり，phosphatase がその生成に触媒的な㗢きをな していることは周知の笔実である。しかるに著者は，卵 趼，貞珠，は主として炭酸カルシウムからできており，

しかも卵殼は Calcite であり，貝殼狩にアュャ 貝㲄では両周に区別され，稜柱層は Calcite， 真珠尿では Aragonite であり，真珠む Ara-

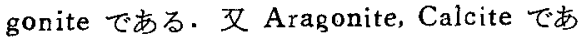
る耳石とその形成過程に何等かの類似点が存在 するのではなかららかと言う品㤝分考えられ る処から，かかる方面の内外交献を涉猟しなが ら検討を加えてみたのである、ところが，卵峘 形成に関しては，Common:4) (1941) が殼の 石灰化に初めて, Carbonic anhydrase (C.A.

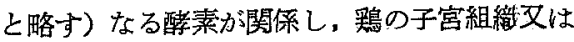

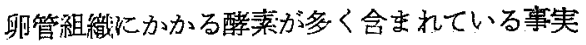
を発見し Gutwska と Mitchell 24)(1945)は C.A. の作用機転について次の上らに説明して 
いる. 即ち C.A. は子宮の分汹細胞内に物ける $\mathrm{H}_{2} \mathrm{CO}_{3}$ の解雅に対して触媒的な働きをなしている.

$$
\begin{aligned}
& 2 \mathrm{HCO}_{3}-= \mathrm{H}_{2} \mathrm{CO}_{3}+\mathrm{CO}_{3}{ }^{--} \\
& \mathrm{H}_{\mathrm{l}} \mathrm{C} . \mathrm{A} . \\
& \mathrm{H}^{2} \mathrm{O}+\mathrm{CO}_{3}
\end{aligned}
$$

子宮内の重炭酸イホンは血液中より得られ，炭酸及び炭 酸イオンを形成する反応を呈し得を・これは不可逆反応 であり、炭酸が蓄積すれば，縠の $\mathrm{CaCO}_{3}$ のために必要 な量の生成を制限するだららと述べ，又一方 Fremann そ Wilbur ${ }^{12}$ (1948) 攻び Bevelander 2) 又本邦では, 辻井 49)（1952）が真珠文び 貝殸形成に C.A. が重要な る因子をなしていることを証明し発表したのである・さ て.C.A.なる酵菜忙 Brinkmann 36) 40) (1931) が初 わてその存在を予想したのである。即ち，血㴼薄めて む，生理的 $\mathrm{pH}$ の下で重炭酸塩より崖酸がスの発生す ることを認め,これは次の

$$
\mathrm{H}_{2} \mathrm{CO}_{3} \rightleftharpoons \mathrm{CO}_{2}+\mathrm{H}_{2} \mathrm{O}
$$

なる反店を促進する何等かの醇素が存在さねばならない 等だと言つた．それに次いで，Meldrum 及び Roughton ${ }^{1 i}$ (1932) が初好てこの䤃紊を牛の血液より白色の 扮末として抽出する事炕成功したのである.

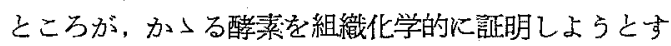
る試みは, 初めて Stadie, O'Brien 16) (1933) に上り, 次いで本邦では倉田 ${ }^{16)}$ (1953)により追試され種なと改 良が加克られている。

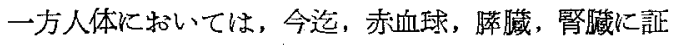
明されてはいるが，耳石器官においては試及たと言ら報 告忧末た知らない。

今回著若は，かつる醅素の耳石形成付する意義を追 求するために，先ず第一段階として，耳石器官にかっる 䤃索の存在の有無を確認する目的で次のような組織化学 的桧索をしたのである。

\section{材料並びに方流}

実駩動物には殿様蛙及び $1.5 \mathrm{~kg}$ ～2.0kg の正常家鷄を 使用した，

\section{実歌力法}

(1) $2 \mathrm{~mm}$ 位の厚さの組織片を冷アセトンで 1 时間固 定.

（2）溜水に上り 10３0 分閒水洗

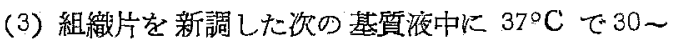
45 分間浸漬する.

$\begin{array}{ll}\text { 塩化マンガン } & 1 \mathrm{~g} \\ 8 \% \text { 重㞸酸》ーダ水溶液 } & 100 \mathrm{cc}\end{array}$

桃色が消えるまで揘找し，後搰過する。

（4）溜水を数回交換して，約 1 時間水洗.

(5) アルロールで脱水, バラフイン包埋, 又はもロイ ギンパラフイン包埋切片作製.

（6）切片を0.1\%過沃素酸カリウム水溶派见入れ, $37^{\circ} \mathrm{C}$ で 48 時間浸清.

（7）溜水て水洗.

(8) $ア=y$ ン色素水溶液で温染色, 脱水, キシロール (この際石炭酸キシロールは使用してはいけない)バル サム封入。

かつる証明法の原理は，適当なる状洗下に就いて，重 岸酸 $\mathrm{Ca}$ の溶液で培盖される時の醇素作用化より炭酸

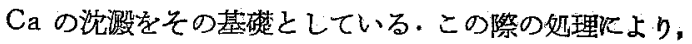
$\mathrm{Ca}\left(\mathrm{HCO}_{3}\right)_{2}$ は $\mathrm{Mn}, \mathrm{Ni}, \mathrm{Co}$ の重炭酸篂により代用せ られる(この場合 $\mathrm{Mn}$ 法, Ni 洗, Co 洗と称する). これを反结式で示すと，この醉素は

$$
\begin{aligned}
& \mathrm{H}_{2} \mathrm{CO}_{3} \rightleftarrows \mathrm{H}_{2} \mathrm{O}+\mathrm{CO}_{2} \\
& \mathrm{Ca}\left(\mathrm{HCO}_{3}\right)_{2} \longrightarrow \mathrm{CaCO} \mathrm{CaCO}_{3}+\mathrm{H}_{2} \mathrm{O}+\mathrm{CO}_{2}
\end{aligned}
$$

の反応式を促進する醉菜であり，酸性炭酸ナトリゥムと 塩化マンガンを基質として，醉素的分解を起すと（Mn 法)

$$
\begin{aligned}
& \mathrm{Mn}\left(\mathrm{HCO}_{3}\right)_{2} \rightleftharpoons \mathrm{MnCO}_{3}+\mathrm{H}_{2} \mathrm{CO}_{3} \rightleftharpoons \mathrm{MnCO}_{3} \\
& +\mathrm{H}_{2} \mathrm{O}+\mathrm{CO}_{2}
\end{aligned}
$$

となり，この場合生ずる $\mathrm{MnCO}_{3}$ の沈澱を 過沃素酸酸 化によつて検出するのである. 即ち

$$
\mathrm{MnCO}_{3}+\mathrm{KJO}_{4}+\mathrm{H}_{2} \mathrm{O} \rightarrow \mathrm{MnO}(\mathrm{OH})_{2}+\mathrm{CO}_{2}+\mathrm{KJO}_{3}
$$
これにより生じた再マンガン酸が醭素の活珄を示し，茶 褐色纴至は黒褐色の顆踥として現われるのである。

更に, Ni 法の場合は, 醭素活性を示寸部位が赤色誦 の影粒として現われ，この場合は， $\mathrm{MnCl}_{2}$ の代りに $\mathrm{NiCl}_{2}$ を用い，過沃素酸カリの代りに $95 \%$ アルュール にlgrのジメチルグリオキシムをとかした溶液を使用 すれば反纫が比較的濑慢性に現われてくる。

\section{成 績}

先ず組織標本作成に当っては，次の点を考慮に入れ， 此較的良好な結果を得た。即ち，

（i）塩化マシガン，8\%重炭酸ソーダ水溶液を混じ搹 找し，濾過した基質液に 普通は30〜40分間浸湭するの であるが， 3 時間程度浸清すれば，その活性度が明膫に 現われてくる。

(ii) $0.1 \%$ 過沃素酸カリウム水溶液を使用するに当つ ては，完全に溚解儿至らないるのでは不成功に終る例が 多いため, 作成值後のあのは使用しない上うにした。 
(iii) 先の過沃素酸カリウム水溶咬中に浸清して和く 蝪合、饔埃を特にさけるよう注意した。

(iv) アニリン色素として，Mn 洗にはェオジンを使 用したが、濃染し過ぎると，顆粒の少い場合は見難くな るのて、、清い過ぎないよう軽く染色する程度にとどめ た。

か稼にして先ず，この䣼素が多量に含まれていると言

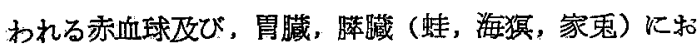
山て，予め当該醭素を証明し，更飞血液 (人間)より C.A. 考 Stadie O'Brien の方法で白色の粉沫として抽 出しこ礼を含をせた，アルブミン膜を上記方法にて染 色し，強陽性の結果を得た・これを参考として，家禡区 び蛙耳石器官に，先ず Mn 法を用いて，その証明を試 みたのである。

周知の通り，耳石器官である情円阆，正円霆共に，そ の微細構造は，単層の扁平上皮よりなり，何れる聴斑を

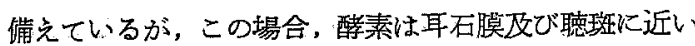
部の body 即ち, Extramaculer potion の一部にも 強い活性を認わたのである((写真 $15,16,17)$.

な招，次に $\mathrm{Ni}$ 法を使用し，上記の部位に一致して，

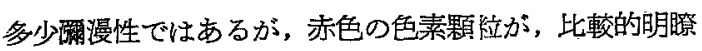
に観察できたのである. 更に対称標本として，(3) の基 質液を蒸溜水として，切片を作成した場合，全く C.A. の活性を認めさる点を確認し，正礁を期した。

\section{小 括}

蛙，家鷄を使用して，組織化学的検索を行つた結果， これ等動物の耳石器官特棌, 耳石膜, 支び Extrama cular potion に強い,C.A. の活性を認めた.

4. C.A. の名種醉索阻止剂による实験

緒 言

酸素反応の阻碍実験は，活性基の性質及び，そ の反店の作用機序を研究する上飞，重要な手がかりを与 えるものである.一方生化学に频いても，いくつかの醉 素系から構成されている中間代謝の複雑な過程を, 阻碍 凧を利用して，いろいろな個所で遮断し，蓄積する中間 物質を分離固定して構造決定を行い，各段階の反応を明 らか炕していこうとする試みがなされている。

页臨床的な面からいつても，抗生物質，化学療法剂な どは，総ぺてある特異な代謝過程を阻碍することによつ

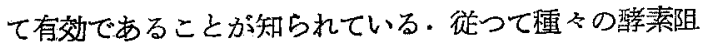

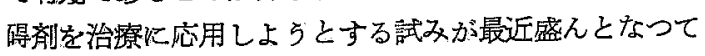
いる。

さて，醉素というものは，極めて不安定な高分子蛋白
体であり，種々なる試诌によつて不活性化される・これ 等の阻碍刘には 2 種類あつて，すべての酵索に対して， 一様作用する非特異的な阻碍削と，ある特定の酵素乃 至は酵素群を，特異的但碍するものとが知られてい る・こつでは後者のみに限定して記述することにする。

そころで, Keilin 仗び Mann ${ }^{24)}$ は R-SO ${ }_{2}: \mathrm{NH}_{2}$ 型 （ $\mathrm{R}:$ ベンゼン，ナフタリン，と゚リジン）の化合物は非 常に俥かではあるが，C.A. を特異的に阻止すると報告 している.

著者は先に C.A.なる䣼素を耳石器官に証明したので

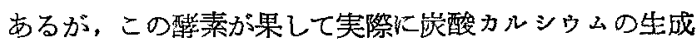
に関与するるのかどらかを証明するため次のよらな実験 を行つた。

材料並びに方法

実験動物としては应卵能力のある $1.5 \mathrm{~kg} 〜 2.0 \mathrm{~kg}$ の建 康なる 10 羽の牝鴧を使用した。

投与せる各種莧剂は次の上らなものである。

(1)

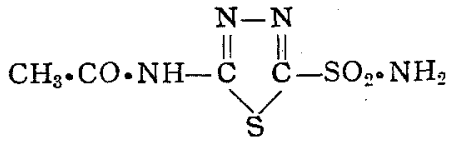
Diamox (Lederle)

(2) $\mathrm{H}_{2} \mathrm{~N}-<->-\mathrm{SO}_{2} \cdot \mathrm{NH}_{2}$ Sulphanilamide

(3) $\mathrm{H}_{2} \mathrm{~N} \cdot \mathrm{O}_{2} \mathrm{~S}-<->-\mathrm{CH}_{2}-<->-\mathrm{SO}_{2} \cdot \mathrm{NH}_{2}$ Nirexon (Bayer)

(4) $\mathrm{S}$

(5) $\mathrm{NaHCO}_{3}$

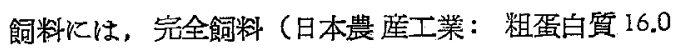

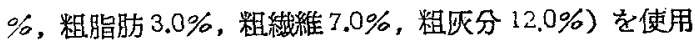
した。

鶏舎には, 各部屋は金網を用い、完全に仕切られ，相互 に交流するを避けた。

\section{方 法}

蒋洞投与に際しては表了に示す量を，ゲラチンカプセ 沉入れ，指先を以って，食道入口部におし入れた後， 4〜5滴の水を注射器にて注入し, 綮くして後, 再度食 道入口部を観察し，正確に领み込んだか否かを確かめ た.投与薬物は表了の如くで，Diamox 4 日間，Nire xon 7 日間, 各\& $5 \mathrm{mg} / \mathrm{kg}$. Sulfathiazole 7 日間, Sulphanilamide 3 日間, 重曹 7 日間, 各 $九 0.2 \mathrm{~g} / \mathrm{kg}$ を 投与し，7\%重曹水（メイロン）は毎日10ce10日間注 射を試みた。 


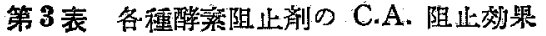

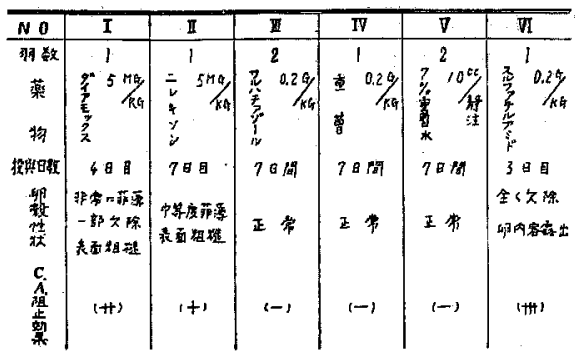

成 樍

Sulphanilamide では，投与後 $l \sim 2$ 日目には卵㲄は

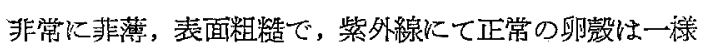
の赤紫色の罃光を呈するに反し Sulphanilamide 投与. 凅殼は，まばらの斑点の多い螢光を発し，3日目では， 写真 No.20 の如く，全く卵款を欠除し，卵内容方露出 していた．Diamox は投与後，4 日目で非常に韭薄， 表面粗徏で，一部欠除せる卵㲄を，又 Nirexon 投与例 でも同様であるが(写真 No.19)，その程度は Diamox に比し軽度で，両者とも柴外線で矢帳り，まばらの斑点 の多い營光を発した．写真 No.18 は特殊な例で Dia. mox $250 \mathrm{mg} ３$ 日間連続投与（全量 $750 \mathrm{mgr}$ ) を行つ たもので，カルシゥム沈着界常の結果と考えられる.こ の卵敖は菲薄で非常に小さく正常卵殼の $1 / 3$ 程度であつ た。次に対象として行った重曹，重曹水注射群に和いて は，先つ゚重曹を試みに $0.5 \mathrm{~g} / \mathrm{kg}$ まで増量し，10日間投 与レしたにも拘らず，卵㲄には㞹等の変化をきたさなかい た. 文 $7 \%$ 重曹水 $10 \mathrm{cc}$ を10 日間任亘り連続静脈这射

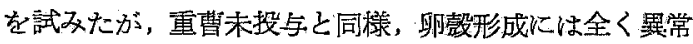
は諗められなかった. 更に Sulfathiazole を投与し， 得られた卵殼も全く正常であつた・な和これ等奏験を通 じて鷭にはチアノーゼ，呼吸困難，餎弱化等の副障碍は

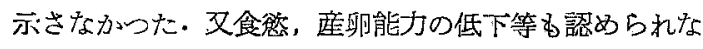
がた.

\section{小 括}

Sulphanilamide, Diamox, Nirexon は明らが, C.A. 阻止作用亡して卵瑴形成即ち炭酸カ几シウムの形 成を阻止したが，特に Sulphanilamide 及び Diamox は影著であつた・これに反し，重曹，7\%雷曹水，Sulfathiazole では全く阻止効果を諗めなからた。

$$
\begin{aligned}
& \text { 5. 総括並びに考按 } \\
& \mathrm{Ca}^{45} \text { による } \mathrm{Ca} \text { 代謝の研究 }
\end{aligned}
$$

最近放射性宫位元素の応用が非常に篮んとなり Radi- oautography 老用いて，放射性物買の存在，分有等を 知る研究も多く行わ机ようになつた：Radioautogra

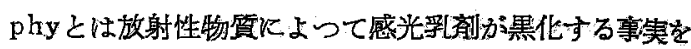
忘用したもので，放射性物質を含も動物の組織片，㕛は細 胞登洙面に感光孚悯膜を直接に接触して，定時間露出 L，現象し，感光乳剂銀粒子の黒化で，放射性物質の分 布像を見る方法である・大体量的分布状態が，宗宙線中 硬 $\gamma$ 線に影響されることなく半永久的に記録されるが， 放射線が放散するために像方济やけるので，微綥構造内 の分皮を明確にする事はできない欠点がある。しかしこ \に使用した放射性同位元素は $\boldsymbol{\beta}$ 線であつて energy が非常に弱いため乳闹中の飛程は短肪くて Radioautography を撮るのに便利である・ただ Ca㗅は energy が特に弱すきるため，感度の低い:Stripping filmには 感光しにくい欠点がある. かつる方法を使用して夷験し た結果， $\mathrm{Ca}^{45}$ は注射後速中为江耳石内に集り，除々に 境加して後消失した勇実を知つたのである.てして更に Ca的の微細なる分布を知るため行つた Microautography は，その操作にでき得る限り万全を期して行つた。 先づ露出時間を決定するため，各切片につき G-M counter で測定したが, 殆んど Natural count と変らな い程度の数值より示さなからた・従つて次に，X 舶つ イルムを用い, 予備実験を行つて, 最大 300 日間の露出 を行い，その間種くなる期間を就いて現像を行つてみ た・しかし明確なる結論を得るまでに至らなかつたのは 逼惑である。このことは先に述べたように，Ca45， energy が弱過ぎる上に Stripping film が特に感度が 低く，長期間の露出により更にその感度を低下させたた めと，その他の微細なる因子が大い閣係しているよう に思われた。

組織化学による C.A. の証明

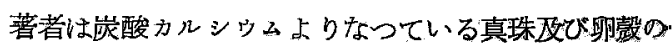
形成に䱋味を持ち，その形成に関与していると思われる Glykogen，多糖類，核酸，Phosphatase 等考取扱 つた論交を多数参照したが最近蔇酸カルシウム形成に C.A. が重要なる因子をなしている報告を知り、との碞 素出現を，耳不器官以举証しよらとする試みは，非常に 合理的であると信じ，先ず蛙に，次いで家鵎の耳石器官 に初めて，C.A. の活性を㒛めたのであるが，特に耳石 膜に一致して，その活性か観察された・そして組織化学 的実駼要に進める内に，聴班に近い部の body 既ち， Extramacular potion に一致して强い活性を諗めたの

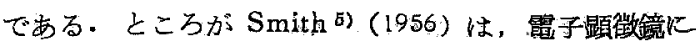


下y 精円琵の body 内に分枝上皮細胞，Bronchial epitheIcelles を実証した。そしてかつる細胞は無数の 突起を出し，基底膜により限界がつけられていて，か〉 西場所で濾過あるいは分泌が行われ，内リンバを座生す るのであらうと推論しているのである.

\section{C.A. の各種䣼素阻止剂に上る実験}

Roblin 及飞び Clapp 20) (1950) は C.A. 抑制体を系統 的追求七遂任 2-Acetylamino-1, 3,4-thiadiarol-5Sulfonamid (略して Acetazolamid) を発見した. こ のむのは有效な内服利尿郕として Diamox と乎ばれ, アメリカで治療に用いられるに至つた. 又ドイッでも以 前より他の種類の即ち，Sulfonamid の C.A. 抑制作 用を研究していたが Schraufstätter ${ }^{21)(1956) ~ は こ れ ~}$ 等の物質を合成し, Schmidt-Kastner ${ }^{21)}$ (1956) は in vivo で C.A. の抑制を検討し, Wolfgang 29) (1957) 及び共同研究者は，Bissulfonamid の一群を見出し， 即ち Diphenyl-methen-4, 4'-Disufonamid xon なる名称で Diamox 同様，内服利尿哓及び緑内 障に和ける眼压降下凨として用いた，又 Corvera ${ }^{6)}$ は Diamox 初めてメニエル氏泟候群患者に使用儿，效 果のある事を実証した・か様な $\mathrm{R}-\mathrm{SO}_{2}: \mathrm{NH}_{2}$ 型の化合 物としての Diamox, Nirexon 及び Sulphanilamide は明らかに炭酸カルシウムよりなる卵款の形成を阻止し たが, Sulphanilamide-Gruppe が置換された化合物で ある Sulfathiazole では全く C.A. 阻止効果のないこ とを示している.

な特 Diamox, Nirexon, Sulphanilamide 2 週間 連続的に投与した結果，8１0日目頃より酥素，即ち 卵敖形成阻止作用が淢弱あるい消失した・一方 Diamox を利尿に使用した実駼でる連用して5〜6日で効果 の減退をみた・その際更に投与量を堌大しても利尿効果 は認められず，数日の休薬期間を和いて投与することに ょり，再び利尿効果を認めているが，著者の例でむ投薬 中止後，1 週間程度で著明な卵㲄形成阻止を観察するこ とができた。

以上より，C.A.が卵殼（炭酸カルシゥム）形成に重 要なる酵素である事を実証したわけであるが，かつる観 点よりして，この酵素が宸酸かルシウムよりなる耳石形 成にも充分必要なる 理由が説明されらるように思われ 子.

な和外りンパ中のCaがいかなる程路を通り，内リン バ腔棌行するかは，現在全く未解決の問題であるが， 以上述べた諸点からして，外りンバ中のカルシウムは，
C.A. の分布せる所謂 Macula の近くのbodyを通り. この部分で酵素の作用をうけ, 内リンパ腔内に移行し， 更に耳石膜中の C.A. の作用により, 初めて炭酸カッシ ウム（耳石）として折出されるのではなかるらかと思考 されるのである(第 5 図).

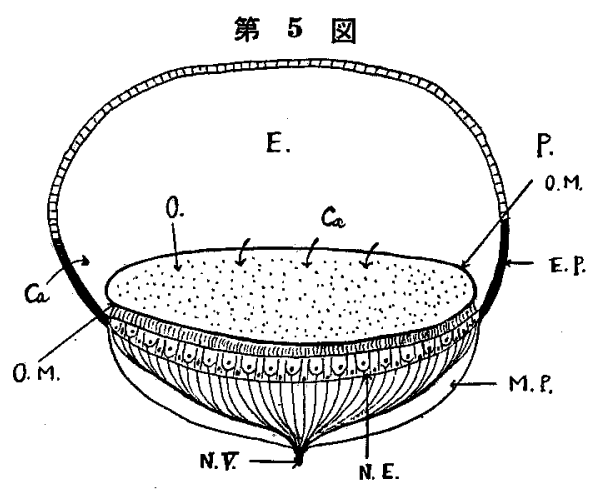

耳石器官模圈

$\mathrm{E}$ ：丙リンパ䐋, $\mathrm{OM}$ ：耳石膜, $\mathrm{O}$ : 耳石,

EP： Extramacular potion, NE：聴斑神経上皮 NV: N, vestib, MP : 膜様壁

\section{III 結 論}

以上蛙，海㺍，家鵎を用い固有の方法を以って，耳石 及び聴斑を摘出し，その本態及び形成に閣する究明を行 い,次のよらな結論仙到達した。

（1）圧迫実験，電子顕微鏡，X線迴折により，耳石 は生体内にあっては，㞸酸かルショムが分散質となり， 歪白質が分散媒として存在する一種のぶルの状態として 存在するものであり，従来耳石結晶として観密された粒 子の集積は耳石膜の破壊，又は化学的，物理的 影響等 で, 耳石膜の非生理的となつた場合，その平衡が破れ微 細結晶質が相集つて結晶の成長をなし，大なる結晶をな するのであつて，非生理的なものと考光る.

(2) $\mathrm{Ca}^{45}$ tracer として，耳石内消長を検索した ところ，Ca $\mathrm{Ca}^{45}$ は投与後，除々に増加し約 72 時程度で交 代する事実から所謂耳石む代謝をなしているすのと考完 られる。

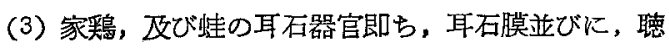
斑に近い:Extramacular potion に集約的に Carbonic Anhydrase を証明した.

（4）当醉素は宸酸カルシウム折出に密接们関与し，耳 石形成に重要なる役割を果するのである。

$$
\text { 参考文献 }
$$

1) Benesch, R.N.S. Barron, and C.A. Mawson: Na- 
ture, $153,138,1944$.

2) Bevelander; G.: Biol, Bull, 102, 9, 1952.

3) Carström, $O$ : J. Histochem, Cytochem, 2, 194, 1954 .

4) Carström, $O$. and Engsrö̈m, H.: Acta Oto-laryng, 65, 14, 1955. 5) Cathalin, A, Smith: Ann. of Otol, 65, 464, 1956. 6) Corvera, J.: Ann, of Otol, 65, 351, 1956. 7) Consuelo Savin V, M.S.: Ann. of Otol, 65, 611, 1956. 8) Consuelo SavinV, M.S.: Ann of Otol, 54, 1019, 1955. 9) Donadai, C.: Zbl. H.N. Kh. 7, 858, 1925 . 10) Engström, H.: Acta Oto-laryng, 60, 5, 1951. 11) Fieandt, H.: Acta Otolaryng, 60, 5, 1951. 12) Freeman, T.A. and Wilbur, K.M.: Biol. Bul1, 94, 55, 1948. 13) Funa. oka, $S$. $u$. Toyota, S.: Folia Anatomica Japonica, 6, 1928 . 14) Giaccai, F. C. Carie, A.: Arch. Otolaryng. 53, 434, $1951 . \quad$ 15) Herzog, H.: Z. Schr. f. Ohren heilk. 12,413, 1925. 16) Kurata. Y.: Stain Technology, 28, 231, 1953. 17) Meldrum, N.V, and Roughton, F.J.W.: Jour. Physiol, 80, 113, 1933. 18) Nishio, S.: Arch. O.N.K. heilk. 115, 19, 1926. 19) Okada, Y.etc: Report of Faculty of Fisheres, perfectural university of mie, 2, 199, 1956. 20) Roblin, R.O. etc: J. Amer. Chem. Soc. 72, 4890, 1950. 21) Schraufstätter, E, Schmidt kastner, G. Wirth, W.: Medizin u. Chemie Bd. V, S 107, 113, 1956. 22) Schwieck, $H, \therefore$ Künstliche Radioactive Isotope in physiologie, Diagnostik. u. Therapie, Berlin, 1953.

23) Studnicka, F.K.:- Arch de Biol, 31, 299, 1921. 24) Surkie, P.D.; Avian. physiology, Comstock Publisning Associated, Ithaca, N.Y., 1954. 25)

Thure, Vilstrup: Ann. of Otol. 60, 974, 1951.

26) Van Goor, H.: Enzymologia, 13, 73, 1948.

27) Wersall J., Engström, H., and Hijorth, S.: Acta Otolaryng. Supp. 116, 298, 1954. 28) $W i$. lbur, K.M. and Anderson, N.G.: Biol, Bull, 98, 12, 1950. 29) Wolfgang, W.: Dtsch. Med. Wschr. 82, 45, 1098, $1957 . \quad 30)$ Wittinaack: Arch. O.N. u. Kh. Heilk. 124; 177, 1930. 31)

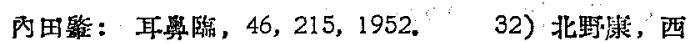
村雅吉他：日化，76,581, 1955. 33) 久保橥之吉：

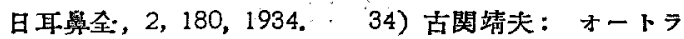
ジオグラフイー，東京，1954. 35）小林新二郎：水
産增殖，3，45,1957。36) 攻口㯵一郎，植村定治郎：

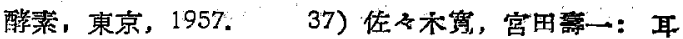

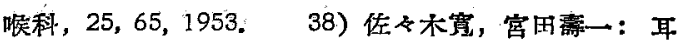

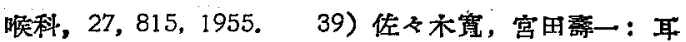
學咽喉科最近の淮步，東京，279，1957。40) 神前武

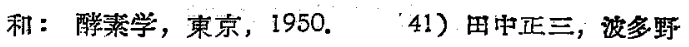
博行：水産增殖，3，38，1957。年）田出正三，波 多野墈行：第一回日本アイソトーブ会議アイントーブ

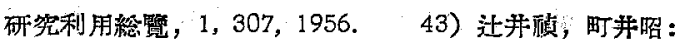
科学，23，148，1953。44）并愿也，倉田自章：日 本病理学会誌，38，108，1949，45）長谷川高钽：耳

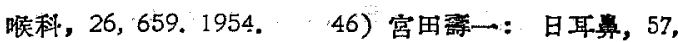

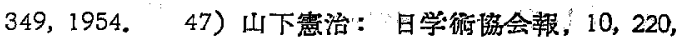

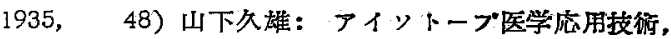
東紊, 1956 。

\section{写 真 説 明}

(No. 1) 压迫実驗：摘出值後の耳石 (蛙). (400x)

(No. 2) 压迫実蛬：乾燥せる耳石 (蛙). $(400 \times)$

(NO. 3) 電子顯微羱写真 (蛙耳石). (28,000x)

(No. 4) 筑子顯微鏡写真（No.3 の拡大写顛） $(40,000$ $\times)$

(No. 5) X 線趌折実験：耳石荧を破り漧燥した耳石 瑰(蛙).

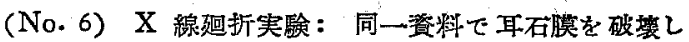
ないままの状貿。

(No. 7) X 線䞟折実験：耳石膜を破り乾燥した耳石 塊 (海崲).

(No. 8) X 線䞟折実験：”同一資料で 耳石膜嵒破壤し なとままの状㴔.

(No. 9) 蛙耳石深沫標本：矢印( $\mathrm{Ca}^{46}$ 注射僛，矢印 な高非注射例.

(No.10) 矢印世㓌影で $\mathrm{Ca}^{45}$ が耳石に移行し 感光せる 像を示す。

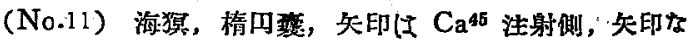
江非注射側。

(No.12) 矢印は除影で $\mathrm{Ca}^{45}$ が耳石に移行し，感光せ る像を示す。

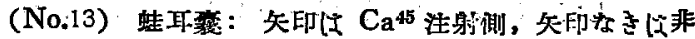
注射側”。

（No.14） Ca45 が耳石膜に移行し，感光さる像を示す。

(No.15) 蛙耳石器官 A: 耳石涘に一致し C.A.の活 性を認も. B：耳石 $(400 x)$

(No.16) 蛙耳石茄官 NE：聴轨の神経上度: 
(No. 1)

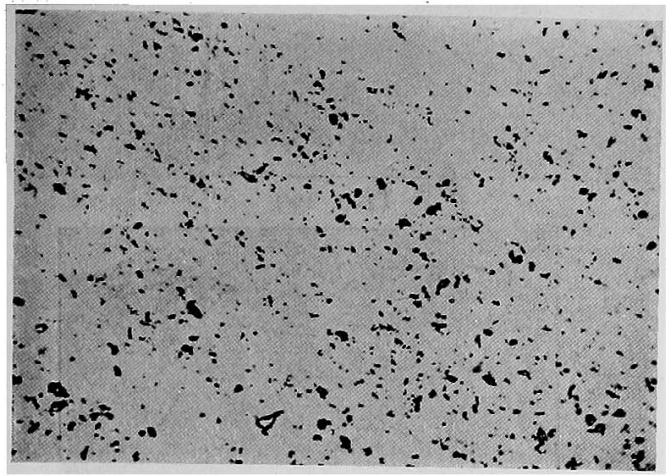

(No. 3)

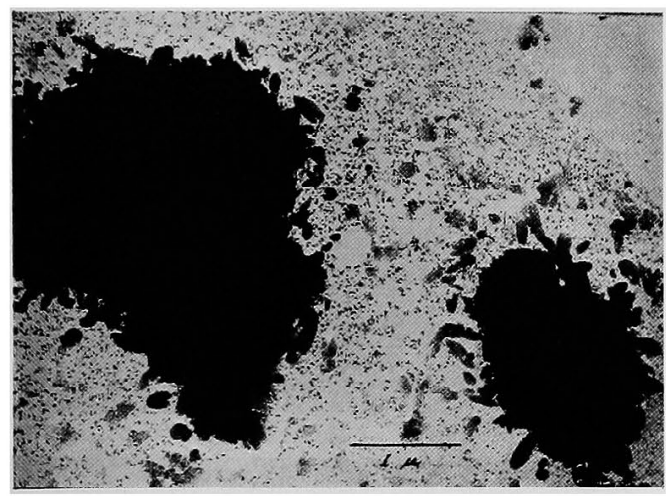

(No, 5)

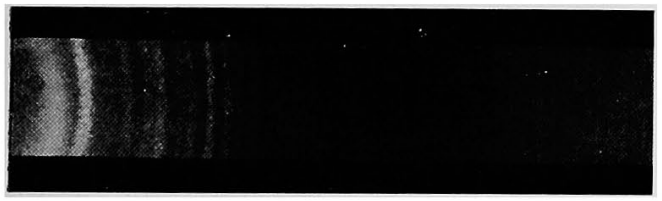

(No. 7)

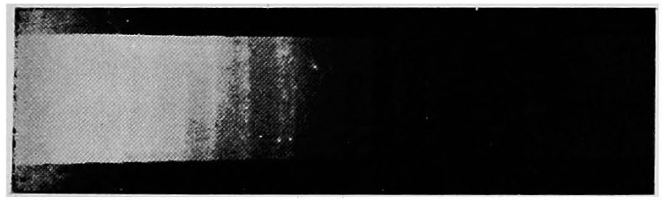

(No. 9)

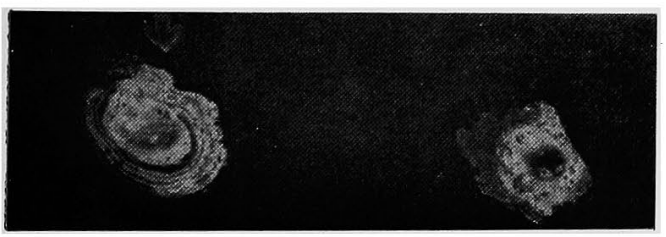

(No. 11)

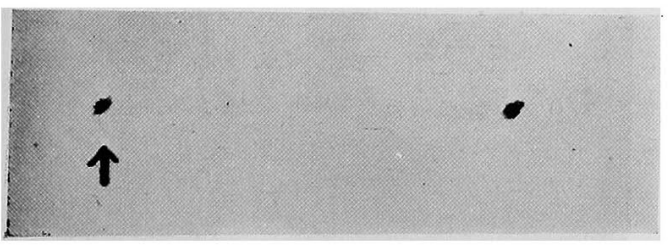

(No. 2)

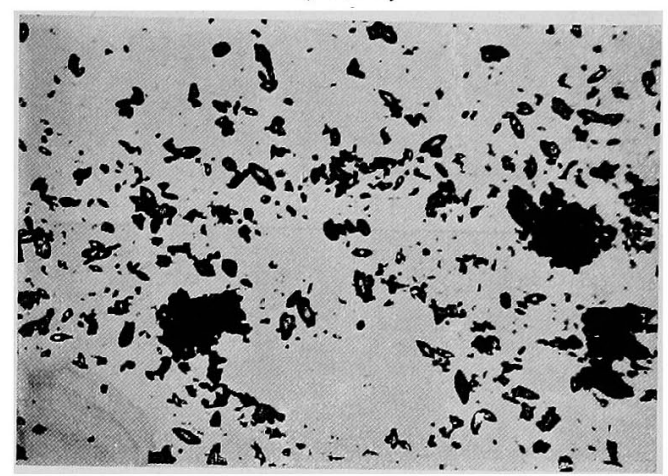

(No. 4)

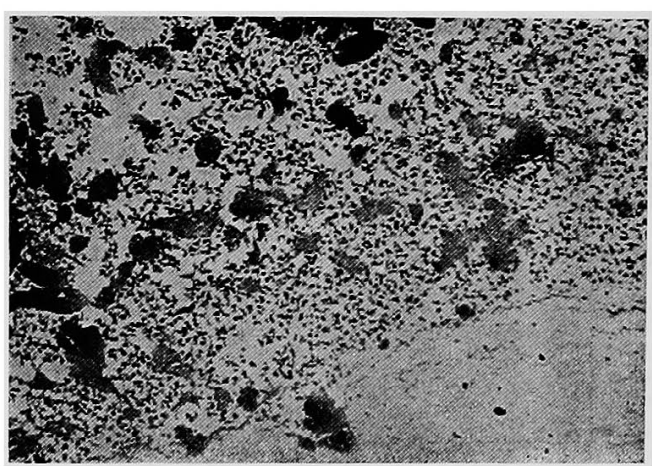

(No. 6)

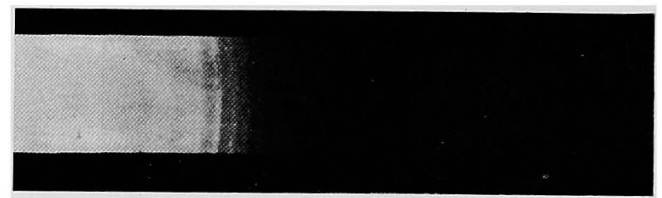

(No. 8)

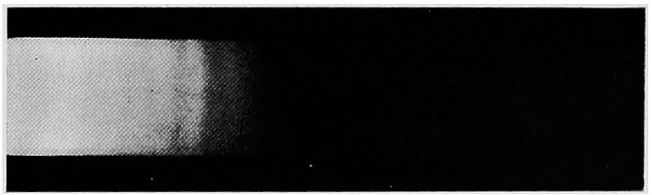

(No. 10)

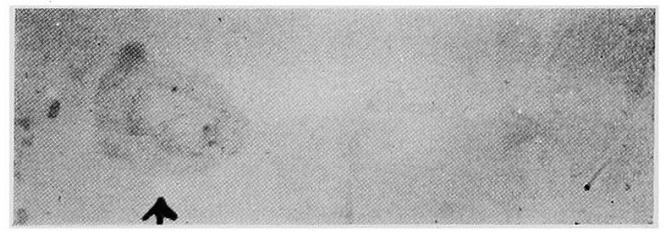

(No. 12)

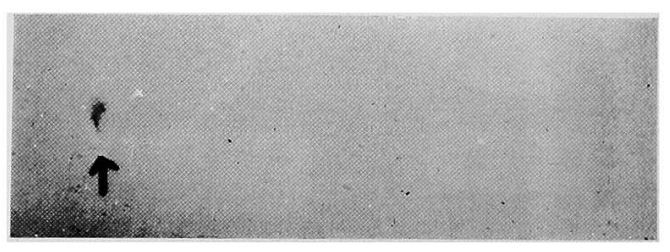


坂口論文附図 (II)

(No. 13)

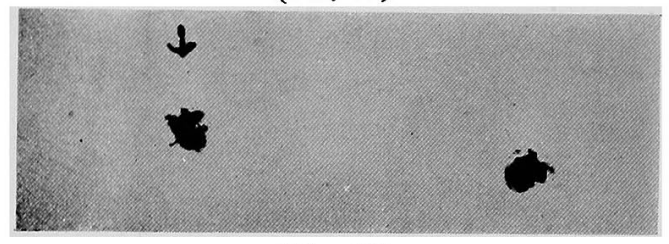

(No. 15)

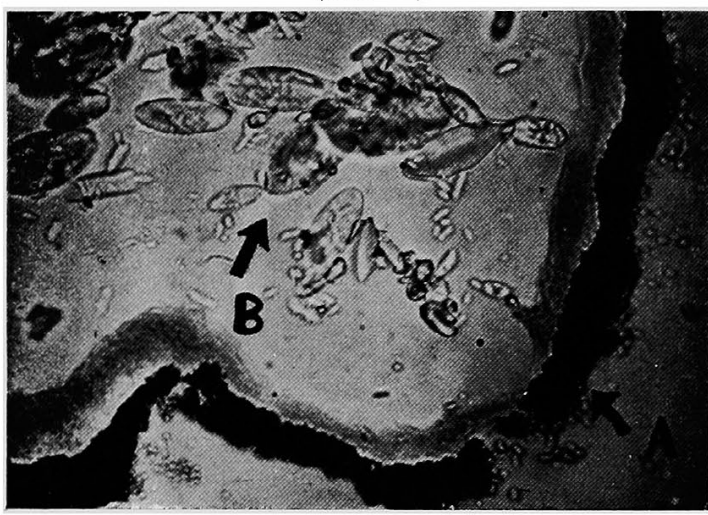

(No. 17)

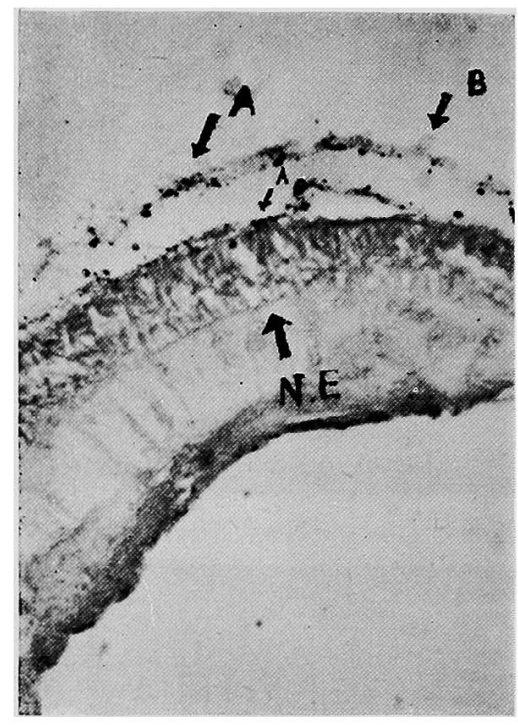

(No. 19)

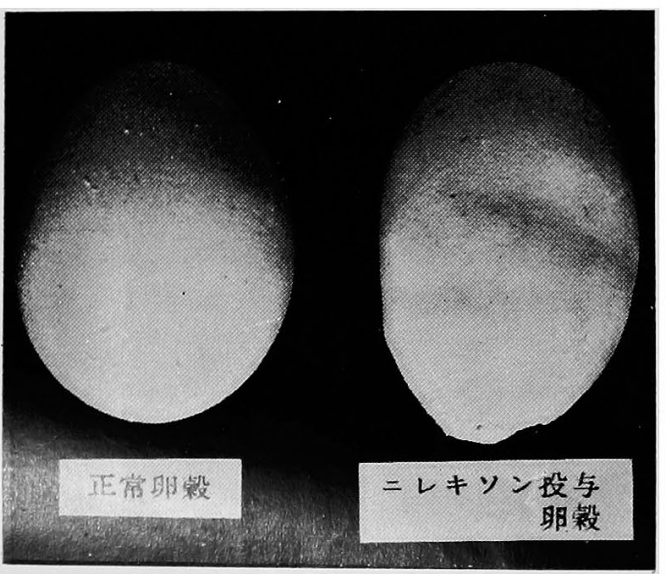

(No. 14)

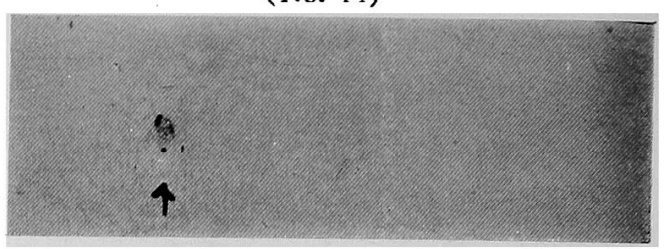

(No. 16)

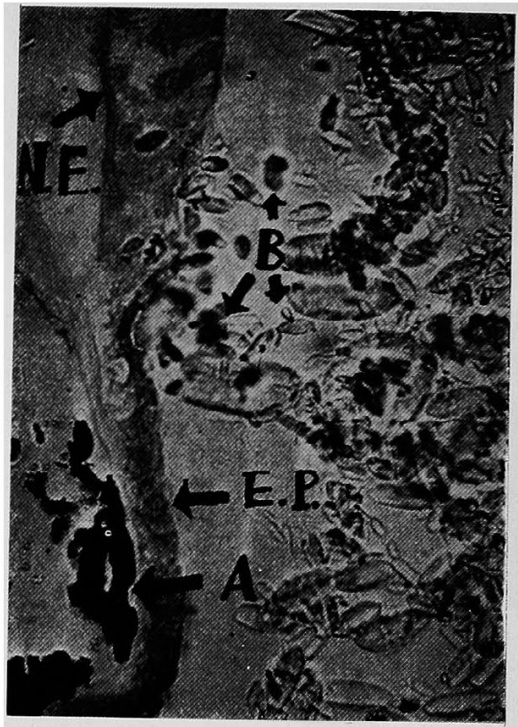

(No. 18 )

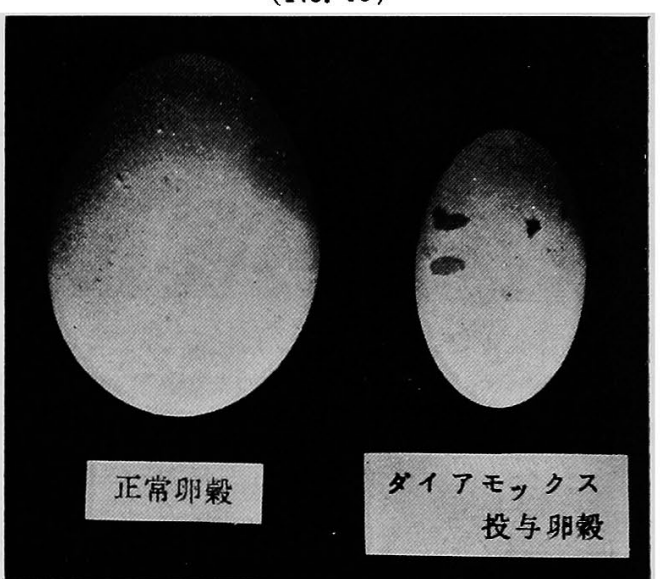

(No. 20)

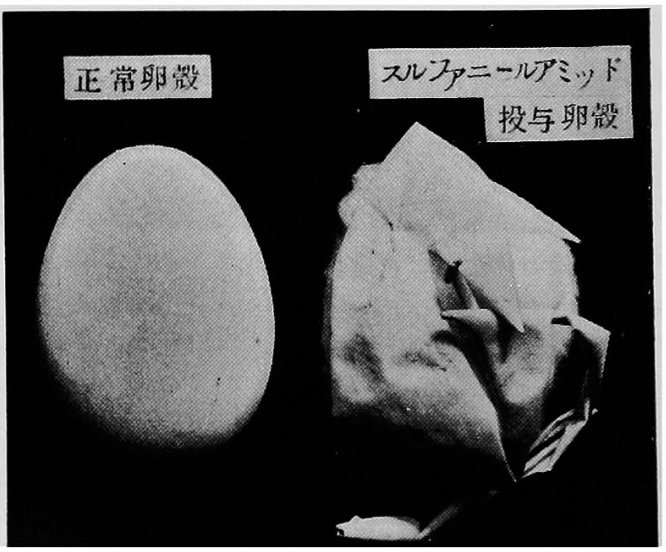


A: Extramacular potion にC.A.の活性を 觍元. B： 耳石 $(400 x)$

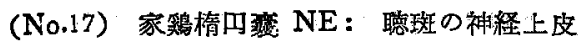

A：耳石膜に一致して C.A.の活性を認む。 (黑色顆粒が䣼素反応部位を示す).

B：耳石，切片作製安殆えど消失す，(400x)

(No.18) Diamox 投与卵㪍て $\mathrm{CaCO}_{3}$ 沈着筫常によ る铅殊な例.

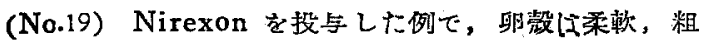
徙で一部欠除している.

(No.20) Sulphanilamide を投与した例で，卵政を全 く灾除した状䁅.

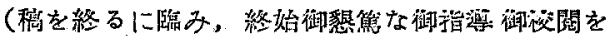

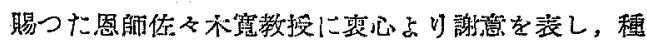
々御教示を顶いた宫田助教授，改び本破究のため に，埸を提供され御助言を賜つた九州大学工学部応 用理学教室，米田助教授に深謝し，併せて金沢大学 医学部病理学教室石川太刀㠛教授, 倉田自音的教授

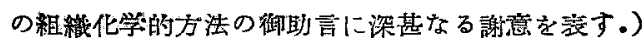

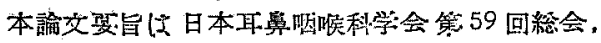

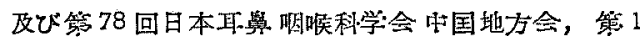

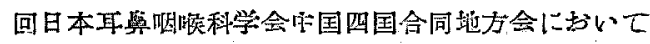
発琵した。

（原稿到着=昭利 34.1.27日一急載） 